\title{
MORPHO-CHEMICAL DIVERSITY IN FESTUCA PRATENSIS AND LOLIUM PERENNE DEPENDING ON CONCENTRATIONS OF ECKLONIA MAXIMA EXTRACT
}

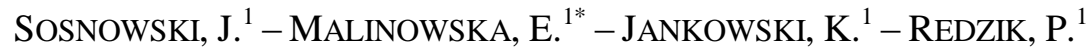 \\ Institute of Agronomy, Siedlce University of Natural Sciences and Humanities, \\ 08 -110 Siedlce, ul. B. Prusa 14, Poland \\ *Corresponding author \\ jacek.sosnowski@uph.edu.pl \\ (Received $25^{\text {th }}$ Nov 2015; accepted $3^{\text {rd }}$ May 2016)
}

\begin{abstract}
The aim of the research was to determine the relationship between application of various concentrations of Ecklonia maxima extract and development of some morphological features, the SAD index as well as selected organic compound content in Festuca pratensis and Lolium perenne. The experiment was replicated three times and the following concentrations of the extract were used: control, $0.04,0.4,4.0$ and $40 \% .40$ days after the extract was sprayed on the plants the following measurements were taken: the number of shoots, the length of leaf blades, the width of the leaf base, the relative chlorophyll index SPAD, and the amount of biomass. The content of protein compounds, simple sugars, lignin, cellulose and hemicellulose were determined after the harvest. The research showed that there was a relationship between a higher concentration of the extract and a higher number of shoots, longer leaf blades and an increase in their width. In consequence of those changes the amount of biomass also increased. The plants sprayed with higher doses of extract had a higher SPAD index, a higher concentration of both protein compounds and simple sugars, and a lower concentration of cellulose, lignin and hemicellulose.
\end{abstract}

Key words: seaweed extract, grass, morphology, sugars, protein

\section{Introduction}

According to Christobel (2008), seaweeds are one of the most important underwater resources and they can be used as food, animal feed or fertiliser in agriculture and horticulture. Such seaweeds as Enteromorpha intestinali, Cladophora dalmatica, Ulva lactuca, Corralina mediterranea, Ascophyllum nodosum and Ecklonia maxima are also a raw material to produce an extract stimulating plant growth on an industrial scale (Bai et al., 2007) Research on a reaction of plants to seaweed extract application was only started a few years ago. It has been found, for example, that because of the content of minerals and growth hormones like IAA and IBA or cytokinin, a seaweed extract can increase disease resistance of agricultural plants (Moller and Smith, 1998, 1999; ElYazied et al., 2012). The extracts contain a variety of chemical compounds and they have a high content of organic calcium, polysaccharides or microelements and a lower content of macro elements: nitrogen, phosphorus and potassium (Crouch and Staden, 1993). Moreover, the extracts have a beneficial impact on plants due to the presence of vitamins and amino acids (Khan et al., 2009; Craigie, 2011). Because of the above advantages Ecklonia maxima extract is considered to be a new generation fertiliser (Wajahatullah et al., 2009). In many publications (Temple and Bomie, 1989; Crouch and Staden, 1991; Zodape, 2001; Bai et al., 2007; Zodapea et al., 2009; El-Yazied et al., 2012; Sosnowski et al., 2013a, 2013b; Kociara et al., 2016), the beneficial effect of seaweed extracts on agricultural plants has been confirmed. It has been said that such 
substances make seed germination faster and increase yield of agricultural plants. It has also been stressed (Wajahatullah et al., 2009) that, unlike mineral fertilisers, substances based on seaweeds are biodegradable, nontoxic and harmless to people and animals. Because of all the above reasons products based on seaweeds are becoming more and more popular. According to Christobel (2008) and Galbiatti et al. (2007), some of the effects of using seaweed extracts are improvement of plant vigour, resistance to disease and to adverse conditions in the environment. Additionally, the use of the extract as a growth stimulant has become popular in horticultural practice because of its beneficial effects (Crouch and Staden, 1993). According to Stirk and Staden (1997), the main ingredients of extracts affecting plant growth are cytokinin and auxin, the presence of which in most seaweeds has been confirmed. These hormones trigger many cytological and histological processes in plants and, according to Wierzbowska and Bowszys (2008), they affect the content of macro elements in biomass.

The aim of the research was to determine the relationship between application of various concentrations of Ecklonia maxima extract and development of some morphological features, the SAD index as well as selected organic compound content in Festuca pratensis and Lolium perenne. The following measurements were taken into account in the experiment: the number of shoots, the length and width of leaf blade, the amount of biomass as well as the content of protein, simple sugars, lignin, cellulose and hemicellulose.

\section{Materials and methods}

\section{The conditions of experiment establish}

The experiment was set up on 12 April 2011 at the experimental station of the University of Natural Sciences and Humanities in Siedlce. 15 plants of Festuca pratensis Huds. (Areus variety) and 15 plants of Lolium perenne L. (Inka variety) were taken from a long-term experimental field and put into Mitscherlich pots of $9 \mathrm{dm}^{3}$ capacity. The pots were put inside into a room with a transparent roof made of plastic. There was a lot of natural light so the plants grew under sunlight with a natural photoperiod. The soil used was loamy medium sand taken from the plough layer. The content of assimilable phosphorus and magnesium in the soil was very high, while potassium and zinc content was high, with an average content of boron, manganese and iron (Table 1).

Table 1. Chemical composition of the soil.

\begin{tabular}{|c|c|c|c|c|}
\hline $\mathrm{pH}$ in $\mathrm{KCL}$ & Humus [\%] & $\mathrm{C}_{\text {org }}\left[\mathrm{g} \mathrm{kg}^{-1}\right]$ & Dry matter [\%] & Humidity [\%] \\
\hline 6.1 & 3.2 & 16.7 & 83 & 12,3 \\
\hline \multicolumn{2}{|c|}{$\begin{array}{l}\text { Content of mineral } \mathrm{N} \\
{\left[\mathrm{mg} \mathrm{kg}^{-1} \mathrm{DM}\right]}\end{array}$} & \multicolumn{3}{|c|}{$\begin{array}{l}\text { Total content of macro elements } \\
{\left[\mathrm{g} \mathrm{kg}^{-1} \mathrm{DM}\right]}\end{array}$} \\
\hline $\mathrm{N}-\mathrm{NO}_{3}$ & $\mathrm{~N}-\mathrm{NH}_{4}$ & $\mathrm{P}$ & $\mathrm{K}$ & $\mathrm{Mg}$ \\
\hline 1.3 & 59.9 & 0.47 & 0.15 & 0.11 \\
\hline \multicolumn{5}{|c|}{$\begin{array}{l}\text { Total content of microelements } \\
{\left[\mathrm{mg} \mathrm{kg}^{-1} \mathrm{DM}\right]}\end{array}$} \\
\hline $\mathrm{B}$ & $\mathrm{Mn}$ & $\mathrm{Cu}$ & $\mathrm{Zn}$ & $\mathrm{Fe}$ \\
\hline 2.0 & 190 & 8.4 & 21.2 & 1567 \\
\hline
\end{tabular}


The mineral fertilisation was as follows: nitrogen $(1.5 \mathrm{~g} \mathrm{~N}$ per pot in the form of $\mathrm{NH}_{4} \mathrm{NO}_{3}$ ), phosphorus ( $0.60 \mathrm{~g}$ P per pot in the form of $\left.\mathrm{KH}_{2} \mathrm{PO}_{4}\right)$, potassium $(1.0 \mathrm{~g} \mathrm{~K}$ per pot in the form of $\left.\mathrm{K}_{2} \mathrm{SO}_{4}\right)$ and magnesium $\left(0.5 \mathrm{~g} \mathrm{Mg}\right.$ per pot in the form of $\left.\mathrm{MgSO}_{4}\right)$. The fertiliser was mixed with the soil and then the pots were filled with it.

All the time during the experiment the soil moisture was $60-70 \%$ of total water capacity. On 15 May the grass was mown to the height of $10 \mathrm{~cm}$ and the extract from Ecklonia maxima (with the brand name of Kelpak SL) was applied in the dose of $3.5 \mathrm{~cm}^{3}$ pot $^{-1}$. There were three experimental units: control (with only distilled water added) and units sprayed with the extract of the concentration $0.04,0.4,4.0$ and $40 \%$, respectively.

According to the producer the chemical composition of the extract was as follows:

- Growth regulators: auxin $11 \mathrm{mg} \mathrm{dm}^{-3}$, cytokinin $0.03 \mathrm{mg} \mathrm{dm}^{-3}$,

- Organic master: carbohydrates $35 \%$, agonic acid 10\%, total amino acid 6\%, manitob 4\%,

- Macro elements: $\mathrm{N} 3.12 \%, \mathrm{P}_{2} \mathrm{O}_{5} 2.61 \%, \mathrm{~K}_{2} \mathrm{O} 4.71 \%, \mathrm{Ca} 0.25 \%, \mathrm{~S} 3.56 \%, \mathrm{Mg}$ $0.58 \%$,

- Micro elements: Fe 150 ppm, Zn 70 ppm, Mn 13 ppm, B 60 ppm, I 30 ppm.

\section{Analysis of morphological and physiological traits}

40 days after the spraying the following measurements were taken: the number of shoots [pieces pot ${ }^{-1}$ ], leaf blade length [cm], the width of the blade base [cm], the SPAD index and dry matter content [g DM pot ${ }^{-1}$.

The measurements of leaf blade length and the width of its base were done using 10 leaves taken at random from each unit. Three replicated analyses of the same leaves were done to determine the SPAD index using the SPAD-502 Spektrum Technologies meter. Moreover, taking advantage of the method described by Janowska (2011), the aspect ratio, an abstract entity, was calculated (leaf length: leaf width) and, using the Kluz-Wieloch (2004) publication, the area index was calculated $\left(\mathrm{cm}^{2}\right)$.

\section{The methods of chemicals estimation}

The plant material was collected, dried and the content of protein compounds, simple sugars, lignin, cellulose and hemicellulose was measured. The airy dry matter was shredded and ground. The obtained material was subjected to chemical analysis to determine dry matter concentration (by determining moisture content) as well as protein compounds and simple sugars concentration. The method of determination was nearinfrared spectroscopy (NIRS) using the NIRFlex N-500 spectrometer and ready to use INGOT calibration applications.

\section{Statistical analysis of the results}

A statistical analysis was performed using Statistica 6.0 for Windows. Data were calculated by ANOVA. The results were verified statistically using analysis of variance. Tukey's test with $\mathrm{p} \leq 0.05$ was applied to find means that were significantly different. Correlation coefficient whose significance was checked using Student's t test. 


\section{Results}

\section{Plant morphology}

This research (Table 2) has shown that higher concentrations of the growth regulator $(40 \%)$, no matter in which species, statistically significantly increased the number of shoots developed by the plants. Festuca pratensis developed more shoots, by $12.8 \%$ on average, than Lolium perenne, no matter what the concentration was.

Table 2. The number of shoots [pieces pot ${ }^{-1}$ ] developed by Festuca pratensis and Lolium perenne in relation to concentration of Ecklonia maxima extract.

\begin{tabular}{|c|c|c|c|c|c|l|}
\hline \multirow{2}{*}{ Species } & \multicolumn{5}{|c|}{ Extract concentration [\%] } & \multirow{2}{*}{ Mean } \\
\cline { 2 - 6 } & Control & 0.04 & 0.4 & 4.0 & 40 & \\
\hline $\begin{array}{c}\text { Festuca } \\
\text { pratensis } \\
\text { Lolium } \\
\text { perenne }\end{array}$ & $28.6 \mathrm{Ab}$ & $30.1 \mathrm{Ab}$ & $29.3 \mathrm{Ab}$ & $32.5 \mathrm{Ab}$ & $38.3 \mathrm{Aa}$ & $31.8 \mathrm{~A}$ \\
\hline Mean & $27.0 \mathrm{Bb}$ & $26.0 \mathrm{Bb}$ & $26.1 \mathrm{Bb}$ & $27.9 \mathrm{Ab}$ & $33.0 \mathrm{Ba}$ & $27.7 \mathrm{~B}$ \\
\hline
\end{tabular}

Mean in line marked with the same small letters don't differentiate significantly, mean in columns marked with the same big letters don't differentiate significantly.

The structure of the above ground part of a plant is determined by the number of shoots as well as the length of the leaf blade and the width of its base, the last two deciding about the size of a leaf blade. As can be seen from Table 3, in the case of Festuca pratensis the longest leaf blades were noted in plants growing in pots sprayed with the extract of $40 \%$ concentration. There was a similar result for Lolium perenne. The width of the leaf base was also related to the concentration of the extract. Both of the test species had the widest leaf base after being treated with the $40 \%$ extract. Analyzing quality parameters of leaf blades it can be said that the aspect ratio of Festuca pratensisleaf blade was the highest for objects sprayed with the $0.4 \%$ extract while for Lolium perenne plants it was the highest when they grew in the control pots. It means only that in those pots the plants grew leaf blades with a high ratio of their width to the length but, when it comes to an impact on yield, the value of the linear correlation coefficient between the area index and the biomass was more representative (Table 4). The value of the linear correlation coefficient between the biomass and the area index was $0.863^{*}$ for Festuca pratensis and $0.793 *$ for Lolium perenne. The area index indicates the relationship between the experimental factor used in the experiment and the size of leaf blades of the plant. The value of this parameter for both species (Festuca pratensis $14.5 \mathrm{~cm}^{2}$, Lolium perenne - $13.9 \mathrm{~cm}^{2}$ ) was the highest for plants sprayed with $40 \%$ concentration of the extract.

Basing on statistical analysis it can be said that the amount of the biomass produced by each plant, Festuca pratensis and Lolium perenne, irrespective of the concentration of the extract, was the same (Table 5), with the average of $54.9 \mathrm{~g} \mathrm{DM}$ pot $^{1}$. There were, however, some differences in the amount of the same plant biomass, depending on various concentrations of the extract. The highest amount of biomass (on average $61.3 \mathrm{~g} \mathrm{DM} \mathrm{pot}^{-1}$ ) was produced by the plants growing in pots where plants were sprayed with the $40 \%$ extract. Compared to the plants sprayed with the highest extract concentration the biomass was on average $13.2 \%$ lower for plants growing in the pots with no extract applied and with the concentration of $0.04,0.4$ and $4 \%$ of the extract. 
Table 3. Relationship between the parameters of Festuca pratensis and Lolium perenne leaf blades and the concentration of Ecklonia maxima extract.

\begin{tabular}{|c|c|c|c|c|}
\hline \multirow{2}{*}{$\begin{array}{c}\text { Extract } \\
\text { concentration } \\
{[\%]}\end{array}$} & \multicolumn{4}{|c|}{ Features } \\
\hline & $\begin{array}{l}\text { Length of } \\
\text { blade }[\mathrm{cm}]^{*}\end{array}$ & $\begin{array}{l}\text { Blade width } \\
{[\mathrm{cm}]^{*}}\end{array}$ & $\begin{array}{l}\text { The aspect } \\
\text { ratio }\end{array}$ & $\begin{array}{c}\text { Area index } \\
{\left[\mathrm{cm}^{2}\right]}\end{array}$ \\
\hline \multicolumn{5}{|c|}{ Festuca pratensis } \\
\hline control & $16.4 \mathrm{C}$ & $0.57 \mathrm{C}$ & 28.8 & 9.35 \\
\hline 0.04 & $18.0 \mathrm{~B}$ & $0.58 \mathrm{C}$ & 31.0 & 10.4 \\
\hline 0.4 & $18.5 \mathrm{~B}$ & $0.67 \mathrm{C}$ & 31.8 & 12.4 \\
\hline 4.0 & $19.2 \mathrm{AB}$ & $0.66 \mathrm{~B}$ & 29.1 & 12.7 \\
\hline 40 & $20.1 \mathrm{~A}$ & $0.72 \mathrm{~A}$ & 27.9 & 14.5 \\
\hline \multicolumn{5}{|c|}{ Lolium perenne } \\
\hline control & $16.0 \mathrm{C}$ & $0.43 \mathrm{~B}$ & 37.2 & 6.88 \\
\hline 0.04 & $16.6 \mathrm{C}$ & $0.49 \mathrm{~B}$ & 33.9 & 8.13 \\
\hline 0.4 & $16.2 \mathrm{C}$ & $0.50 \mathrm{~B}$ & 32.4 & 8.10 \\
\hline 4.0 & $17.5 \mathrm{C}$ & $0.54 \mathrm{AB}$ & 32.4 & 9.45 \\
\hline 40 & $22.1 \mathrm{~A}$ & $0.63 \mathrm{~A}$ & 35.1 & 13.9 \\
\hline
\end{tabular}

"Mean in columns marked with the same big letters don't differentiate significantly

Table 4. The value of linear correlation coefficient between dry matter of Festuca pratensis as well as Loluim multiflorum and leaf blade parameters.

\begin{tabular}{|l|l|}
\hline \multicolumn{1}{|c|}{ Leaf quality parameters } & \multicolumn{1}{c|}{$\begin{array}{c}\text { Biomass } \\
{\left[\mathrm{g} \mathrm{DM} \mathrm{pot}^{-1}\right]}\end{array}$} \\
\hline \multicolumn{2}{|c|}{ Festuca pratensis } \\
\hline y. the aspect ratio & \\
\hline y. area index & $0.532^{*}$ \\
\hline \multicolumn{2}{|c|}{ Lolium perenne } \\
\hline y. aspect ratio & $0.863^{*}$ \\
\hline y. area index & $0.598^{*}$ \\
\hline
\end{tabular}

*Significant with $\mathrm{p} \leq 0,05$.

Table 5. Relationship between the amount of the biomass [ $\left.\mathrm{g} D M \mathrm{pot}^{-1}\right]$ for Festuca pratensis and Lolium perenne and the concentration of Ecklonia maxima extract.

\begin{tabular}{|c|c|c|c|c|c|c|}
\hline \multirow{2}{*}{ Species } & \multicolumn{5}{|c|}{ Extract concentration [\%] } & \multirow{2}{*}{ Mean } \\
\cline { 2 - 6 } & control & 0.04 & 0.4 & 4.0 & 40 & \\
\hline $\begin{array}{c}\text { Festuca } \\
\text { pratensis }\end{array}$ & $48.8 \mathrm{Ab}$ & $53.8 \mathrm{Ab}$ & $56.8 \mathrm{Aab}$ & $54.3 \mathrm{Ab}$ & $60.1 \mathrm{Aa}$ & $54.8 \mathrm{~A}$ \\
\hline $\begin{array}{c}\text { Lolium } \\
\text { perenne }\end{array}$ & $50.9 \mathrm{Ab}$ & $52.8 \mathrm{Ab}$ & $55.1 \mathrm{Aa}$ & $53.7 \mathrm{Ab}$ & $62.5 \mathrm{Aa}$ & $55.0 \mathrm{~A}$ \\
\hline Mean & $49.6 \mathrm{~b}$ & $53.3 \mathrm{~b}$ & $56.0 \mathrm{~b}$ & $54.0 \mathrm{~b}$ & $61.3 \mathrm{a}$ & \\
\hline
\end{tabular}

Mean in line marked with the same small letters don't differentiate significantly, mean in columns marked with the same big letters don't differentiate significantly. 
The values of the SPAD index of test grass leaf blades varied throughout the experiment depending on the concentration of the growth stimulant. The measurements of the index showed that plants sprayed with the $40 \%$ extract had a bigger value of SPAD (Table 6) and the index value for those plants was 30\% higher than for plants in the control pots.

Table 6. Relationship between the Festuca pratensis as well as Lolium perenne SPAD index value and Ecklonia maxima extract concentration.

\begin{tabular}{|c|c|c|c|c|c|l|}
\hline \multirow{2}{*}{ Species } & \multicolumn{5}{|c|}{ Extract concentration [\%] } & \multirow{2}{*}{ Mean } \\
\cline { 2 - 6 } & control & 0.04 & 0.4 & 4.0 & 40 & \\
\hline $\begin{array}{c}\text { Festuca } \\
\text { pratensis }\end{array}$ & $28.6 \mathrm{Ac}$ & $27.8 \mathrm{Ac}$ & $31.7 \mathrm{Ab}$ & $33.0 \mathrm{Ab}$ & $39.3 \mathrm{Aa}$ & $37.8 \mathrm{~A}$ \\
\hline $\begin{array}{c}\text { Lolium } \\
\text { perenne }\end{array}$ & $29.4 \mathrm{Ac}$ & $30.0 \mathrm{Ac}$ & $34.0 \mathrm{Ab}$ & $33.9 \mathrm{Ab}$ & $44.0 \mathrm{Ba}$ & $34.4, \mathrm{~B}$ \\
\hline Mean & $29.0 \mathrm{c}$ & $28.9 \mathrm{c}$ & $32.9 \mathrm{~b}$ & $33.5 \mathrm{~b}$ & $41.7 \mathrm{a}$ & \\
\hline
\end{tabular}

Mean in line marked with the same small letters don't differentiate significantly, mean in columns marked with the same big letters don't differentiate significantly.

It is worth noting that the use of the $0.4 \%$ and $4 \%$ also made the SPAD index grow in a statistically significant way, when compared to the control and to the plants sprayed with $0.04 \%$ extract. Yet the growth was significantly smaller than for plants sprayed with the highest concentration of the stimulant. Irrespective of the extract concentration, for Festuca pretensis the SPAD index was higher on average by $9.9 \%$ while the value of SPAD for leaf blades of the same

\section{Chemical analysis}

Apart from affecting the amount and structure of the biomass of the above ground part of plants the Ecklonia maxima growth stimulant also increased the amount of protein and simple sugars in the plants (Table 7). Irrespective of the species and compared to the control, applying even $0.4 \%$ extract increased protein content in the dry matter by $19 \%$ on average and simple sugars content by $27 \%$. It is worth noting that applying the extract with a higher concentration of 4 and $40 \%$ did not result in a higher protein and sugars content, the value of which did not differ significantly from the content of protein and sugars in plant sprayed with the $0.4 \%$ extract. However, spraying grass with the $0.04 \%$ extract did not increase the content of those substances in biomass. Apart from that, it was noticed that irrespective of the extract concentration the content of protein and sugars was higher in the dry matter of Lolium perenne.

Table 7. Relationship between protein and simple sugar content $\left[\mathrm{g} \mathrm{kg}^{-1} \mathrm{DM}\right]$ in the biomass of the above ground part of Festuca pratensis as well as Lolium perenne and different concentrations of Ecklonia maxima extract.

\begin{tabular}{|c|c|c|c|c|c|c|}
\hline \multirow{2}{*}{ Species } & \multicolumn{5}{|c|}{ Extract concentration [\%] } & \multirow{2}{*}{ Mean } \\
\cline { 2 - 6 } & Control & 0.04 & 0.4 & 4.0 & 40 & \\
\hline \multicolumn{7}{|c|}{ Protein compounds } \\
\hline $\begin{array}{c}\text { Festuca } \\
\text { pratensis }\end{array}$ & $84.1 \mathrm{Bb}$ & $79.9 \mathrm{Bb}$ & $98.8 \mathrm{Ba}$ & $97.9 \mathrm{Ba}$ & $100.1 \mathrm{Ba}$ & $92.2 \mathrm{~B}$ \\
\hline
\end{tabular}




\begin{tabular}{|c|c|c|c|c|c|c|}
\hline $\begin{array}{c}\text { Lolium } \\
\text { perenne }\end{array}$ & $92.1 \mathrm{Ab}$ & $95.3 \mathrm{Ab}$ & $111.2 \mathrm{Aa}$ & $108.0 \mathrm{Aa}$ & $110.7 \mathrm{Aa}$ & $103.5 \mathrm{~A}$ \\
\hline Mean & $88.1 \mathrm{~b}$ & $87.6 \mathrm{~b}$ & $105.0 \mathrm{a}$ & $103.0 \mathrm{a}$ & $105.4 \mathrm{a}$ & \\
\hline \multicolumn{6}{|c|}{ Simple sugars } \\
\hline $\begin{array}{c}\text { Festuca } \\
\text { pratensis }\end{array}$ & $73.8 \mathrm{Bb}$ & $79.0 \mathrm{Bb}$ & $98.2 \mathrm{Ba}$ & $90.9 \mathrm{Ba}$ & $95.6 \mathrm{Ba}$ & $87.5 \mathrm{~B}$ \\
\hline $\begin{array}{c}\text { Lolium } \\
\text { perenne }\end{array}$ & $111.4 \mathrm{Ab}$ & $110.8 \mathrm{Ab}$ & $138.3 \mathrm{Aa}$ & $141.1 \mathrm{Aa}$ & $140.8 \mathrm{Aa}$ & $128.5 \mathrm{~A}$ \\
\hline Mean & $92.6 \mathrm{~b}$ & $94.9 \mathrm{~b}$ & $118.3 \mathrm{a}$ & $116.0 \mathrm{a}$ & $118.2 \mathrm{a}$ & \\
\hline
\end{tabular}

Mean in line marked with the same small letters don't differentiate significantly, mean in columns marked with the same big letters don't differentiate significantly.

One of the effects of growth stimulant application is a decrease of the amount of cellulose, hemicellulose and lignin in test plants (Table 8). Like in the case of protein compounds and simple sugars only $0.4,4$ and $40 \%$ extracts were significantly effective in comparison to the control pots. Irrespective of the grass species spraying plants with the extract lowered the concentration of cellulose by $7 \%$, hemicellulose by $9 \%$ and lignin by $13 \%$ in the biomass of the plants. It is worth noting that out of the two grass species Festuca pratensis dry matter had a bigger concentration of cellulose, hemicellulose, irrespective of the extract concentration. For both species lignin concentration was the same, $44.4 \mathrm{~g} \mathrm{~kg}^{-1} \mathrm{DM}$ on average, without significant differences between them.

Table 8. Relationship between Ecklonia maxima concentration [ $\mathrm{g} \mathrm{kg}^{-1}$ S.m.] and cellulose, hemicellulose and lignin content in the above ground biomass of Festuca pratensis and Lolium perenne.

\begin{tabular}{|c|c|c|c|c|c|c|}
\hline \multirow{2}{*}{ Species } & \multicolumn{5}{|c|}{ Extract concntration [\%] } & \multirow{2}{*}{ Mean } \\
\hline & Control & 0.04 & 0.4 & 4.0 & 40 & \\
\hline \multicolumn{7}{|c|}{ Cellulose $\left[\mathrm{g} \mathrm{kg}^{-1}\right.$ s.m. $]$} \\
\hline $\begin{array}{l}\text { Festuca } \\
\text { pratensis }\end{array}$ & $320.4 \mathrm{Aa}$ & $323.8 \mathrm{Aa}$ & $304.7 \mathrm{Ab}$ & $301.7 \mathrm{Ab}$ & $308.1 \mathrm{Ab}$ & $311.7 \mathrm{~A}$ \\
\hline $\begin{array}{l}\text { Lolium } \\
\text { perenne }\end{array}$ & $297.1 \mathrm{Ba}$ & $298.1 \mathrm{Ba}$ & $267.3 \mathrm{Bb}$ & $271.2 \mathrm{Bb}$ & $265.9 \mathrm{Bb}$ & $279.9 \mathrm{~B}$ \\
\hline Mean & $308.8 \mathrm{a}$ & $311.0 \mathrm{a}$ & $286.0 \mathrm{~b}$ & $286.5 \mathrm{~b}$ & $287.0 \mathrm{~b}$ & \\
\hline \multicolumn{7}{|c|}{ Hemicellulose $\left[\mathrm{g} \mathrm{kg}^{-1}\right.$ s.m.] } \\
\hline $\begin{array}{c}\text { Festuca } \\
\text { pratensis }\end{array}$ & $227.1 \mathrm{Aa}$ & 230.0 Aa & $208.5 \mathrm{Ab}$ & $200.8 \mathrm{Ab}$ & $210.2 \mathrm{Ab}$ & $215.3 \mathrm{~A}$ \\
\hline $\begin{array}{l}\text { Lolium } \\
\text { perenne }\end{array}$ & $199.5 \mathrm{Bb}$ & $198.1 \mathrm{Bb}$ & $182.0 \mathrm{Bb}$ & $179.7 \mathrm{Bb}$ & $187.2 \mathrm{Bb}$ & $189.3 \mathrm{~B}$ \\
\hline Mean & $213.3 \mathrm{a}$ & $214.1 \mathrm{a}$ & $195.3 \mathrm{~b}$ & $190.3 \mathrm{~b}$ & $198.7 \mathrm{~b}$ & \\
\hline \multicolumn{7}{|c|}{ Lignin [ $\mathrm{g} \mathrm{kg}^{-1}$ s.m.] } \\
\hline $\begin{array}{c}\text { Festuca } \\
\text { pratensis }\end{array}$ & 49.1 Aa & $48.9 \mathrm{Aa}$ & 44.7 Ab & $43.7 \mathrm{Ab}$ & $45.6 \mathrm{Ab}$ & $46.4 \mathrm{~A}$ \\
\hline $\begin{array}{c}\text { Lolium } \\
\text { perenne }\end{array}$ & $46.9 \mathrm{Aa}$ & 47.3 Aa & $38.2 \mathrm{Ab}$ & $39.0 \mathrm{Ab}$ & $40.1 \mathrm{Ab}$ & $42.3 \mathrm{~A}$ \\
\hline Mean & $48.0 \mathrm{a}$ & $48.1 \mathrm{a}$ & $41.5 \mathrm{~b}$ & $41.4 \mathrm{~b}$ & $42.9 \mathrm{~b}$ & \\
\hline
\end{tabular}


Mean in line marked with the same small letters don't differentiate significantly, mean in columns marked with the same big letters don't differentiate significantly.

\section{Discussion}

According to many publications (Temple and Bomke, 1989; Zodape, 2001; Sosnowski et al., 2013a, 2013b) growth regulator Kelpak does not do any damage to plants but stimulates their growth and improves their stress resistance. Sultan (2005) says that the effect of substances based on phytohormones depends strongly on their concentration, the way they are applied and on the species and variety of the plant. Many publications (Temple and Bomie, 1989; Zodape, 2001; Fornes et al., 2002; Thirumaran et al., 2009) confirm that Ecklonia maxima extract increases the size of some plant organs. There have been experiments with Festuca pratensis and Lolium perenne which also confirmed the beneficial effect of the extract. Application of the extract resulted in an increase in the number of shoots and leaf blade area of the plants, which contributed to a higher amount of biomass. At the same time the SPAD index value also increased. In another experiment (Bai et al., 2007) foliar treatment of plants with algae extract brought about an increase in shoot length by $35 \%$ and roots by $22 \%$, when compared to the control. Thevanathan et al. (2005) present similar results while. Godlewska and Ciepiela (2013) deal with the effects of the Kelpak growth stimulant on plant yield. It has to be stressed, however, that there have been experiments described in literature where no significant effect of the extract on plants was noted (Temple and Bomie, 1989; Nour et al., 2010; Zodape et al., 2010; Sridhar and Rengasamy, 2011). Yet in most cases scientific research has confirmed beneficial effect of Kelpak on crop yield, at the same time showing that the time of the extract application is more important than the dose (Godlewska and Ciepiela, 2013; Sosnowski et al., 2013a, 2013b). It has also been proved (Godlewska and Ciepiela, 2013) that new varieties of the same species may react in a different way to the same regulator. According to Szabo et al. (2011), components in biostimulants such as auxins, gibberellic acid, cytokinins and amino acids increase the physiological activity of plants, for example protein synthesis. There are many reports in the world literature of the positive effect of sea algae extracts on protein content in various plant species (Sivasankari et al., 2006). Joubert and Lefranc (2008) have stated that active substances in sea algae extracts are similar to physiological activators in their mode of action because they may change the chemical composition of plants sprayed with such extracts. The biostimulant applied in the present study was found to influence the concentration of sugars in plants. Kelpak increased monosaccharide concentration in grasses by 37.6\%, regardless of the remaining factors investigated in the study. Similar findings have been reported by many authors (Güllüoglu, 2011; Pacholczak et al., 2012) who have stressed that sea algae extracts contribute to increased sugar contents in plants but, as with protein content. Godlewska and Ciepiela (2013) also studied the relationship between 0.5\% Ecklonia maxima extract and an increase of protein and simple sugar content. They applied the growth stimulant to Dactylis glomerata as well as to Festulolium braunii and the result was an $11 \%$ growth of protein compounds and a 37\% growth of simple sugars content in the biomass of the test grass. When both grass species were compared, a higher sugar/protein ratio was calculated for Festulolium braunii although Kelpak significantly increased the value of this indicator for both the species. The sugar/protein ratio was also different between harvests. Ratios calculated for consecutive regrowths 
were significantly lower whereas increasing values were obtained for consecutive cuts when Kelpak had been applied. Analysis of the results showed that carbohydrate/protein ratios in the tested plants decreased in consecutive study years, the differences being statistically significant.

\section{Conclusions}

The research has shown that the effects of Ecklonia maxima extract application on Festuca pratensis and Lolium perenne were related to the concentration of the extract applied. The best results, with an increase in biomass of the above part of plants, an increase in the number of shoots as well as the length and width of the leaf blade, were achieved when $40 \%$ extract concentration was used. The increase of the SPAD index was statistically significant when even lower doses of the extract were used $(0.4$ and $4 \%$ ). Yet the highest increase of the SPAD index was when $40 \%$ extract was applied to the plants. Compared to the control, only the $0.04 \%$ extract did not affect the content of protein, simple sugars, cellulose or lignin. When the extract of the $0.4,4$ and $40 \%$ concentration was applied, then the content of protein and simple sugars increased, whereas the content of polysaccharides in the dry matter decreased.

\section{REFERENCES}

[1] Bai, N.R., Banu, N.R.L., Prakash, J.W., Goldi, S.J. (2007): Effects of Asparagopsis taxiformis extract on the growth and yield of Phaseolus aureus. - J. Basic. Appl. Biol.1: 6-11.

[2] Christobel, J.G. (2008): Effect of seaweed (Sargassum wightii L.) on the germination and growth of green gram (Phaseolus Aureus L.). - J. Basic. Appl. Biol. 2: 105-108.

[3] Craigie, J.S. (2011): Seaweed extract stimuli plant science and agriculture. - J. Appl. Phycol . 23: 371-393.

[4] Crouch, I.J., Staden, J. (1991): Evidence for rooting factors in a seaweed concentrate prepared from Ecklonia maxima. - J Plant Physiol. 137: 319-322.

[5] Crouch, I.J., Staden, J. (1993): Effect of seaweed concentrate from Ecklonia maxima (Osbeck) Papenfuss on Meloidogyne incognita infestation on tomato. - J Appl. Phycol. 5: 37-43.

[6] El-Yazied, A., El-Gizawy, A.M., Ragab, M.I., Hamed, E.S. (2012): Effect of seaweed extract and compost treatments on growth, yield and quality of snap bean. - J Am. Sci. 8: $1-20$.

[7] Fornes, F., Sa`nchez-Perales, M., Guadiola, J.L. (2002): Effect of a seaweed extract on the productivity of 'de Nules' clementine mandarin and navelina orange. - Bot. Mar. 45: 486-489.

[8] Galbiattia, J.A., Cavalcantea, I.H.L., Ribeiroa, A.G., Pissarraa, T.C.T. (2007): Nitrate and sodium contents on lettuce and drained water as function of fertilizing and irrigation water quality in Brazil. - Int. J Plant Prod. 1: 205-214.

[9] Godlewska, A., Ciepiela, G.A. (2013): The effect of natural growth regulators obtained from ecklonia maxima and mineral nitrogen on true protein and simple sugar contents of Dactylis glomerata L. and Festulolium braunii (K. Richt.) A. Camus. - Turk. J Field Crops. 18: 247-253

[10] Güllüoglu, L. (2011): Effects of growth regulator applications on pod yield and some agronomic characters of peanut in Mediterranean region. - Turk. J Field Crops. 16(2): 210-214. 
[11] Janowska, B. (2011): Effect of flurprimidol and benzyladenine on growth and flowering of calla lily (Zantedeschia spreng.) cultivated in pots. - Science Nature Technol. 5(1): 19.

[12] Joubert, J.M., Lefranc, G. (2008): Seaweed phytostimulants in agriculture: recent studiem on mode of action two types of products from alga:growth and nutrition stimulants and stimulants of plant Demence reactions. Book of abstracts: Biostimulators in modern agriculture. Warsaw, p.16.

[13] Khan, W., Rayirath, U.P., Subramanian, S., Jithesh, M.N., Rayorath, P., Hodges, D.M., Critchley, A.T., Craigie, J.S., Norrie, J., Prithiviraj, B. (2009): Seaweed extracts as biostimulants of plant growth and development. - Plant Growth Regul. 28: 386-399.

[14] Kluza-Wieloch, M. (2004): Variability and heritability of morphological features of stems and leaves in observed types of sunflower (Helianthus annuus L.) cultivars. - Rocz. AR Pozn. CCCLXIII, Bot. 7: 149-165.

[15] Kocira, A., Świeca, M., Kocira, S., Złotek, U., Jakubczyk A. (2016): Enhancement of yield, nutritional and nutraceutical properties of two common bean cultivars following the application of seaweed extract (Ecklonia maxima). - Saudi J. Biol Sci. doi:10.1016/j.sjbs.2016.01.039

[16] Molle, M., Smith, M.L. (1999): The effect of pruning treatments using seaweed suspensions on the water sensitivity of Barley (Hardeum vulgare L.) caryopses. - Ann. Appl. Biol. 135: 515-522.

[17] Moller, M., Smith, M.L. (1998): The significance of the mineral component of seaweed suspension on lettuce (Lactuca sativa L.) seedling growth. - J Plant Physiol. 153: 658663.

[18] Nour, K.A.M., Mansour, N.T.S., Abd El-Hakim, W.M. (2010): Influence of foliar spray with seaweed extracts on growth, setting and yield of tomato during summer season. - J Plant Prod. 7: 961-976.

[19] Pacholczak, A., Szydło, W., Jacygard, E., Federowicz, M. (2012): Effect of auxins and the biostimulator algaminoplant on rhizogenesis in stem cuttings of two dogwood cultivars (Cornus alba 'Aurea' and 'Elegantissima'). - Acta Sci. Pol. Hortorum Cultus 11(2):93-103.

[20] Sivasankari, S., Venkatesalu, V., Anantharaj, M., Chandrasekaran, M. (2006): Effect of seaweed extracts on the growth and biochemical constituents of Vigna sinensis. Bioresour. Technol. 97:1745-1751.

[21] Sosnowski, J., Jankowski, K., Wiśniewska-Kadżajan, B. (2013a): Effect of Kelp SL on the formation of above-ground biomass of Festulolium braunii (K. Richt.) A. Camus. Acta Agrobot. 2: 149-154. DOI:10.5586/aa.2013.031.

[22] Sosnowski, J., Jankowski, K., Wiśniewska-Kadżajan, B., Jankowska, J. (2013b): Effect of different concentrations of Kelpak bioregulator on the formation of above-ground biomass cocksfoot. - J Ecol. Eng. 1: 48-52. DOI:10.5604/208139X.1031536.

[23] Sridhar, S., Rengasamy, R. (2011): Efeect of seaweed liquid fertilizer on the growth, biochemical constituents and yield of Tagetes erecta, under field trial. - J Phytology. 6: 61-68

[24] Stirk, W.A., Van Staden, J. (1997): Isolation and identification of cytokinins in a new commercial seaweed product made from Fucus serratus L. - J Appl. Phycol. 9: 327-330.

[25] Sultana, V., Ehteshamul-Haque, S., Ara, J., Athar, M. (2005): Comparative efficacy of brown, green and red seaweeds in the control of root infecting fungi and okra. - Int. J Environ. Sci. Tech. 2: 129-132.

[26] Szabo, V., Sarvari, A., Hrotko, K. (2011): Treatment of Stockplants with biostimulators and their effects on cutting propagation of prunus Marianna GF8-1. - Acta Hort. 923:277-282.

[27] Temple, W.D., Bomke, A.A. (1989): Effects of kelp (Macrocystis integrifolia and Ecklonia maxima) foliar applications on bean crop growth. - Plant Soil 117: 85-92. 
[28] Thevanathan, R., Dinamani, D.S., Bhavani, L.G. (2005): Studies on the impact of application of marine algal manure and liquid fertiliser on the linear growth of the seedlings of some pulses. - Seaweed Res. Utili. 27: 125-133.

[29] Thirumaran, G., Arumugam, M., Arumugam, R., Anantharaman, P. (2009): Effect of seaweed liquid fertilizer on growth and pigment concentration of Cyamopsis tetrogonolaba (L) Taub. - Am-Euras. J Agron. 2: 50-56.

[30] Wajahatullah, K., Usha, P.R., Sowmyalakshmi, S., Mundaya, N.J., Prasanth, R., Hodges, A., Critchley, T., Craigie, J.S., Norrie, J., Prithiviraj, B. (2009): Seaweed extracts as biostimulants of plant growth and development. - J Plant Growth Regul. 28: 386-399. DOI 10.1007/s00344-009-9103-x

[31] Wierzbowska, J., Bowszyc, T. (2008): Effect of growth regulators applied together with different phosphorus fertilizations levels on the content and accumulation of potassium, magnesium and calcium in spring wheat. - J Elem. 13: 411-422.

[32] Zodape, S.T. (2001): Seaweeds as a biofertilizer. - J Sci. Industrial Res. 60: 378-382.

[33] Zodape, S.T., Mukhopadhyay, S., Eswaran, K., Reddy, M.P., Chikara, J. (2010): Enhanced yield and nutritional quality in green gram (Phaseoulus radiata L.) treated with seaweed (Kappaphycus alvarezii) extract. - J Sci. Industrial Res. 69: 468-471.

[34] Zodapea, S.T., Mukherjeea, S., Reddya, M.P., Chaudharya, D.R. (2009): Effect of Kappaphycus alvarezii (Doty) ex silva. extract on grain quality, yield and some yield components of wheat (Triticum aestivum L.). - Int. J Plant Prod. 3: 97-101. 